\title{
Bamboo as a Sustainable Building Material-Culm Characteristics and Properties
}

\author{
Kitti Chaowana ${ }^{1}$, Supanit Wisadsatorn ${ }^{2}$ and Pannipa Chaowana ${ }^{3,4,5,6, *(D)}$ \\ 1 School of Languages and General Education, Walailak University, Nakhonsithammarat 80160, Thailand; \\ ckitti@mail.wu.ac.th \\ 2 School of Architecture and Design, Walailak University, Nakhonsithammarat 80160, Thailand; \\ supanit.wi@wu.ac.th \\ 3 School of Engineering and Technology, Walailak University, Nakhonsithammarat 80160, Thailand \\ 4 Center of Excellence on Wood and Biomaterials, Walailak University, Nakhonsithammarat 80160, Thailand \\ 5 Center of Excellence for Bamboos, Kasetsart University, Bangkok 10903, Thailand \\ 6 Center of Excellence on Petrochemical and Materials Technology, Bangkok 10330, Thailand \\ * Correspondence: mpannipa@mail.wu.ac.th; Tel.: +66-75672312
}

Citation: Chaowana, K.;

Wisadsatorn, S.; Chaowana, P.

Bamboo as a Sustainable Building

Material-Culm Characteristics and

Properties. Sustainability 2021, 13,

7376. https://doi.org/10.3390/

su13137376

Academic Editors: Ilaria Capasso,

Giuseppe Brando and Gianluca Iezzi

Received: 31 May 2021

Accepted: 28 June 2021

Published: 1 July 2021

Publisher's Note: MDPI stays neutral with regard to jurisdictional claims in published maps and institutional affiliations.

\begin{abstract}
Bamboo culm is a renewable and lightweight material with high strength, particularly tensile strength. It is well accepted that bamboo culms have played a significant role in architecture because of their sustainable contribution. The culm characteristics and properties of three-year-old bamboo from five species (Dendrocalamus asper, Dendrocalamus sericeus, Dendrocalamus membranaceus, Thyrsostachys oliveri, and Phyllostachys makinoi) were investigated. The results show that each bamboo species has different culm characteristics along with culm length. Culm size, particularly the outer culm diameter and culm wall thickness, affects the ultimate load. These results confirm that a bigger culm with a thicker wall could receive more load. D. asper received the highest ultimate load, while T. oliveri received the lowest ultimate load. However, when calculating the test results for stress (load per cross-section area), P. Makinoi showed excellent mechanical properties, while D. asper showed the worst mechanical properties. This research promotes bamboo's appropriate use for building applications and as a more sustainable material for architecture.
\end{abstract}

Keywords: bamboo culm; sustainable natural material; building material; culm characteristics; physical and mechanical properties

\section{Introduction}

In architecture, one of the activities aligned with SDGs, especially Goal 11 (Sustainable Cities and Communities), supports developed countries in building sustainable and resilient buildings utilizing local materials. These materials should be inexpensive, permanently available, have excellent physical and mechanical properties, and be environmentally friendly. For this situation, bamboo has received considerable attention because it is described as low cost, easily and locally available, and high strength. Besides, bamboo is known as an environmentally friendly, fast-growing, and renewable resource material that only takes three years to mature and become ready for collection.

Bamboo is the common name of the perennial grass with a large woody stem or culm. Bamboo encompasses about 1662 species within 121 genera [1]. Only a few bamboo species belonging to the Guadua, Dendrocalamus, Bambusa, and Phyllostachys genera are typically used for construction [2]. The bamboo culm is the aboveground part of the bamboo that contains most of the woody material. The culm is complimented by a branching system, sheath, foliage leaves, flowers, fruits, and seedlings. Bamboo culm develops in one period of growth by a delicately timed cell elongation process with some cell division. When new culms appear, they already have attained their ultimate diameter. Unlike trees, bamboos have no secondary thickening growth. Naturally, the culm is straight, hollow, and cylindrical with node and internode parts. 
Bamboo culm has been widely known as a relatively environmentally friendly and sustainable building material to replace the use of conventional materials such as wood, brick, concrete, and steel [3]. This material has been widely used as the primary building material in many countries, especially in Asia, Africa, and South America. Consequently, it is used for flooring, ceiling, walls, windows, doors, roofs, trusses, and rafters in buildings. Moreover, it is also used as structural material for bridges, water transportation, and skyscraper scaffolding. Bamboo is being addressed as a building material contributing to sustainable development because it shows distinctively qualified environmental, social, and economic benefits [4].

In Thailand, bamboo is one of the most socio-economically important species. It is generally found in mixed deciduous forests. There are 15 genera and 80 species of bamboos recorded in Thailand [5]. Some bamboo species are planted for culm production, including the following:

- D. asper is one of the most popular bamboo species of Thailand. Its culms have thick walls. They are very strong and durable and are used as a building material for houses and bridges, furniture, musical instruments, chopsticks, household products, and handicrafts.

- D. sericeus is a moderately large bamboo with tightly clustered, straight, bluish-green culms with a large diameter. The thick-walled culms are advantageous for producing laminated bamboo lumber products such as glued laminated bamboo beams, floors, and cutting boards.

- D. membranaceus is a medium-sized clumping bamboo. Its culms are straight and usually between $20-24 \mathrm{~m}$ high and $6-10 \mathrm{~cm}$ in diameter. The internodes are covered with a white powdery deciduous scurf when young but become green upon maturity. This species is suitable for building purposes, furniture, bamboo boards, agricultural implements, household products, and as props for fruit trees. It is also one of the most promising species for paper pulp.

- T. oliveri is a tropical clumping bamboo with short rhizomes. Its culms are straight with a small diameter. The culms are valued as a local source of material for construction. Moreover, they are also used to reinforce concrete blocks, basketry, handicraft, and broom handles.

- $\quad$ P. makinoi is an evergreen bamboo. The rhizomes are elongated, with the plant having a running habit that can produce new shoots some distance from the main clump. Its culm is hard and dense and is stiffly erect. The culms are widely used in construction, furniture, pulpwood, handicraft, and splits for weaving.

It has been postulated that the fundamental properties of bamboo culm need to be studied before bamboo is accepted as one of the building materials. This research investigated the culm characteristic variations and the physical and mechanical properties of five bamboo species in Thailand. Specimens were taken from the different parts (node and internode) and portions (bottom, middle, and top) of the culm to compare and identify some factors affecting the performance of the bamboo culm for structural applications. Moreover, this article investigated the various properties of bamboo culm and how they could be used in architectural design.

\section{Materials and Methods}

\subsection{Raw Material Sampling and Preparation}

Five species of three-year-old bamboo were used in this study because they are widely planted for culm production. D. asper and D. membranaceus were collected from the Wang Nam Khiao bamboo living collections, Nakhon Ratchasima, Thailand. D. sericeus, T. oliveri, and P. makinoi were harvested from the Maehia bamboo collection plot at the Royal Project Foundation, Chiang Mai, Thailand. Five culms were randomly collected from five randomly selected clumps. The culms were cut to a height of about $20 \mathrm{~cm}$ above ground level. Each culm was cut into three portions (bottom, middle, and top) at $3 \mathrm{~m}$ long, labeled, and measured according to the standard ISO 22157-2: 2004 [6]. 
The untreated bamboo was air-dried under the shed and transported to the Center of Excellence on Wood and Biomaterials, Walailak University, Nakhonsithammarat, Thailand, for further investigation.

\subsection{Investigation of Bamboo Culm Characteristics}

After felling, the culm characteristics (e.g., culm length, internode length, outer culm diameter, and culm wall thickness) from the bottom towards the top were investigated as presented in Figure 1.
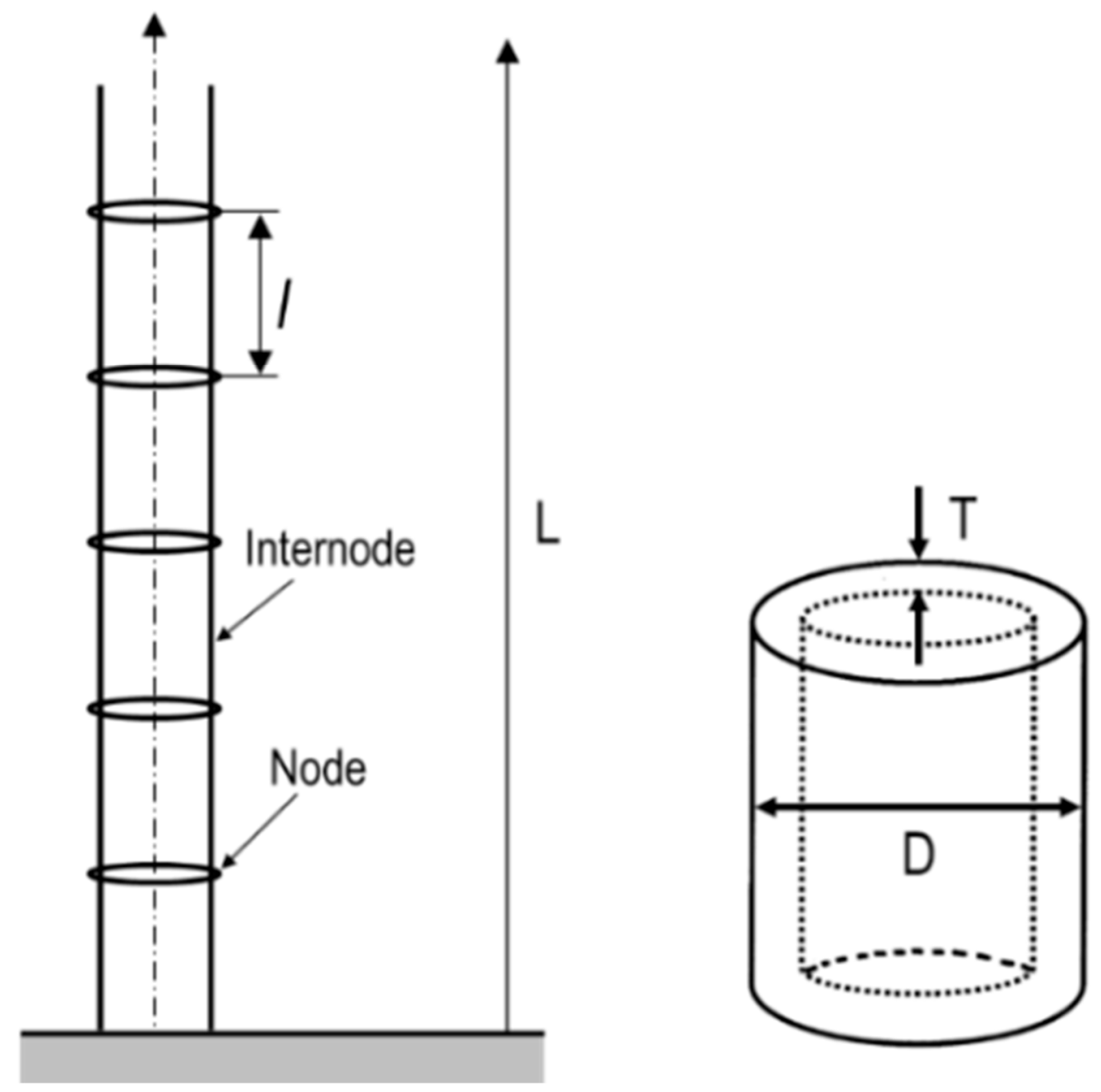

Figure 1. Simulation picture of the bamboo culm characteristics; L = Length of bamboo culm, $1=$ Length of internode; $\mathrm{D}=$ Outer culm diameter, and $\mathrm{T}=$ Culm wall thickness.

\subsection{Examination of Bamboo Culm Properties}

Bamboo culms were cut into specific sizes according to the standard requirement. They were then placed in a conditioning chamber at a temperature of $27 \pm 2{ }^{\circ} \mathrm{C}$ and relative air humidity of $70 \pm 5$ percent for six weeks before the physical and mechanical properties were investigated according to ISO 22157-1: 2004 [7].

- Moisture content: Samples of $25 \mathrm{~mm} \times 25 \mathrm{~mm} \times$ wall thickness were taken near the failure location to determine moisture content and density. The samples were cut from the different parts (node and internode). The initial weight before drying was weighed. Then, the samples were dried in an oven at a temperature of $103 \pm 2{ }^{\circ} \mathrm{C}$. After $24 \mathrm{~h}$, the mass was recorded. For each test piece, the moisture content $(M C)$ was calculated by using Equation (1).

$$
\operatorname{MC}(\%)=\frac{\left(m_{1}-m_{0}\right)}{m_{0}} \times 100
$$


where $m_{1}$ is the mass before drying $(\mathrm{g})$ and $m_{0}$ is the mass after oven drying $(\mathrm{g})$.

- Density: The samples used in the determination of moisture content were the same used for density determination. The oven-dried density $(D)$ of each sample was calculated using Equation (2).

$$
D\left(\mathrm{~kg} / \mathrm{m}^{3}\right)=\frac{m_{0}}{V} \times 10^{6}
$$

where $m_{0}$ is the mass of the sample after oven drying $(\mathrm{g})$ and $V$ is the sample volume $\left(\mathrm{mm}^{3}\right)$.

- Shear strength parallel to grain test: The samples were taken from the node and internode parts along the culm length. The sample length was equal to the outer culm diameter. The test was carried out by using a universal testing machine. The specimens were supported at the lower end over two quarters. The load was applied at the upper end over the two quarters with a constant speed of $0.01 \mathrm{~mm} / \mathrm{s}$. Figure 2a shows the setup of the shear strength parallel to grain test. The ultimate shear strength parallel to the grain $\left(\tau_{\text {ult }}\right)$ was calculated using Equation (3). The density and moisture contents were determined for each specimen.

$$
\tau_{u l t}(\mathrm{MPa})=\frac{F_{u l t}}{A_{s}}
$$

where $F_{u l t}$ is the maximum shear load at which the sample failed $(\mathrm{N})$ and $A_{s}$ is the total failed area $\left(\mathrm{mm}^{2}\right)$.

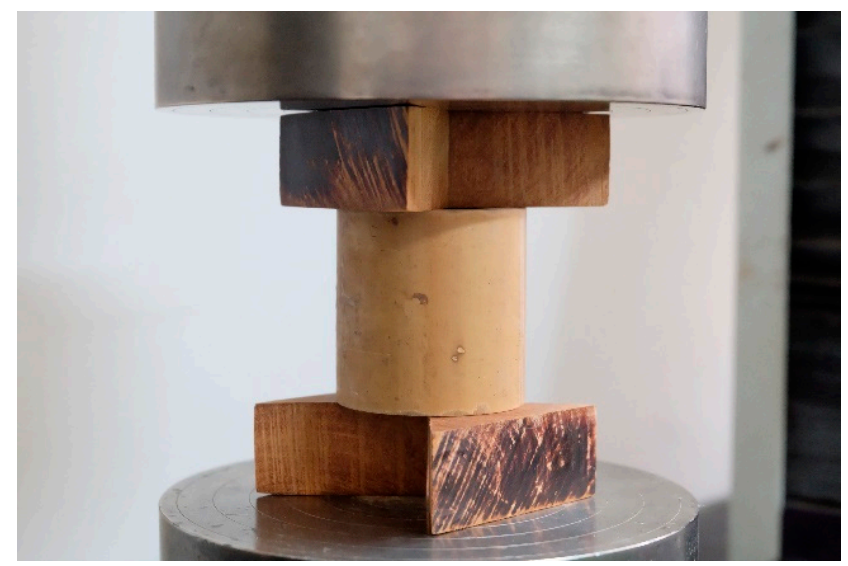

(a)

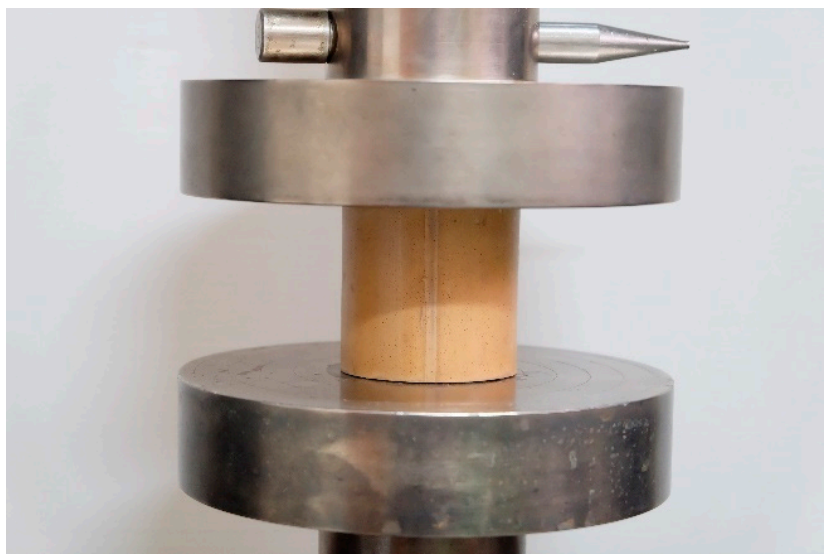

(c)

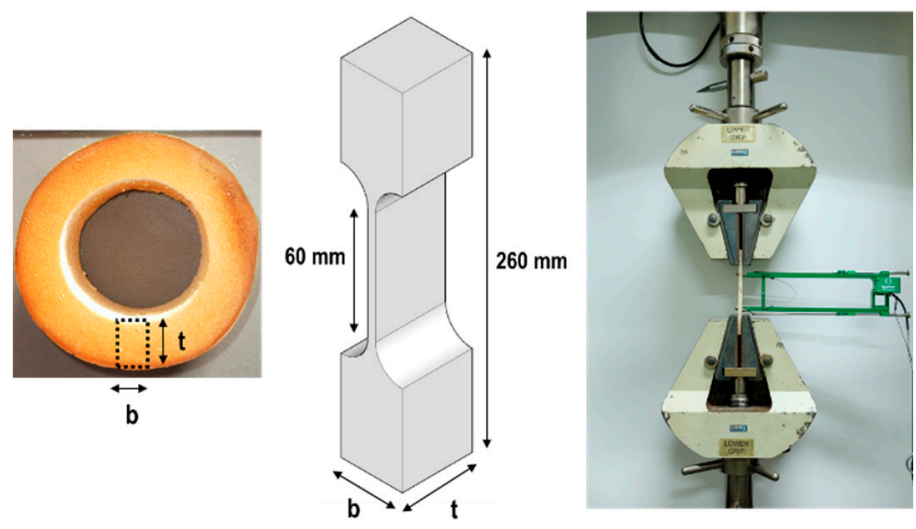

(b)

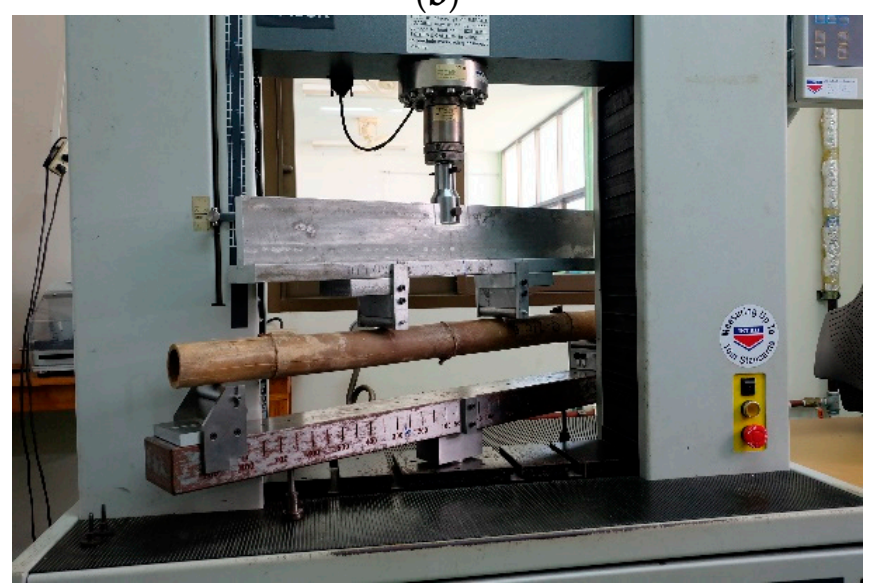

(d)

Figure 2. The test setup for (a) shear strength parallel to grain test, (b) tensile strength parallel to grain test, (c) compressive strength parallel to grain test, and (d) four-point bending test. 
- Tensile strength parallel to grain test: In order to compare the effects of the node and internode parts on tensile strength parallel to the grain, the test was conducted on specimens prepared in wedge shapes with the node and internode parts, as shown in Figure 2b. The specimen length was $260 \mathrm{~mm}$ with a $20 \mathrm{~mm}$ width of the specimen grip. The gauge length of specimens was $65 \mathrm{~mm}$, the width was $10 \mathrm{~mm}$, and the thickness was according to the culm wall thickness. Both ends of the specimens were tightly clamped between the metal grips of a universal testing machine, as presented in Figure 2b. The tensile load was applied to the specimens at a constant rate of $0.01 \mathrm{~mm} / \mathrm{s}$. The ultimate tensile strength parallel to the grain $\left(\sigma_{u l t}\right)$ was calculated by using Equation (4). Failure of the specimens outside the gauge part was discarded. The density and moisture contents were determined from the gauge part for each specimen.

$$
\sigma_{u l t}(\mathrm{MPa})=\frac{F_{u l t}}{A}
$$

where $F_{u l t}$ is the maximum tensile load at which the specimen failed $(\mathrm{N})$ and $A$ is the area of the gauge part that failed $\left(\mathrm{mm}^{2}\right)$.

- Compressive strength parallel to grain test: The specimens without nodes were prepared. The specimen length was equal to the outer culm diameter (D) or ten times the culm wall thickness (10T). The test was performed using a universal testing machine. The load was applied through a metal bearing plate, as shown in Figure 2c, which was placed across the upper surface of the culm wall thickness and at right angles to the specimen length. The load was applied at a constant speed of $0.01 \mathrm{~mm} / \mathrm{s}$. The maximum compressive strength parallel to the grain $\left(\sigma_{u l t}\right)$ was calculated by using Equation (5). The density and moisture contents were determined for each specimen.

$$
\sigma_{u l t}(\mathrm{MPa})=\frac{F_{u l t}}{A}
$$

where $F_{\text {ult }}$ is the maximum load at which the sample failed $(\mathrm{N})$ and $A$ is the crosssectional area $\left(\mathrm{mm}^{2}\right)$.

- Bending strength test: The four-point static bending test method was performed with some modifications to ISO 22157-1: 2004 [7], because of the limitation of span length. The samples with $1 \mathrm{~m}$ length were tested using a universal testing machine equipped with a computerized data acquisition system. The load was applied at midway between the centers of the device supports, as illustrated in Figure 2d, with a constant speed of the movable crosshead at $0.5 \mathrm{~mm} / \mathrm{min}$ until specimen failure occurred. The Modulus of Rupture (MOR) and Modulus of Elasticity (MOE) were calculated by using Equations (6) and (7), respectively. The specimens were cut near the point of failure for specific gravity and moisture content determinations.

$$
\begin{gathered}
\operatorname{MOR}(\mathrm{MPa})=F \times L \times \frac{\frac{D}{2}}{6} \times I_{B} \\
\operatorname{MOE}(\mathrm{MPa})=\frac{23 \times F \times L^{3}}{1296 \times \delta \times I_{B}}
\end{gathered}
$$

where $F$ is the maximum load $(\mathrm{N}), L$ is the free span $(\mathrm{mm}), D$ is the outer culm diameter $(\mathrm{mm}), I_{B}$ is the second moment of area $\left(\mathrm{mm}^{4}\right)$, and $\delta$ is the deflection mid-span $(\mathrm{mm})$.

\section{Results and Discussion}

\subsection{Characteristic of Bamboo Culm}

The culm is the aboveground part of the bamboo, which mainly contains woody material. It is straight, hollow, and cylindrical with node and internode parts, as presented in Figure 3. 


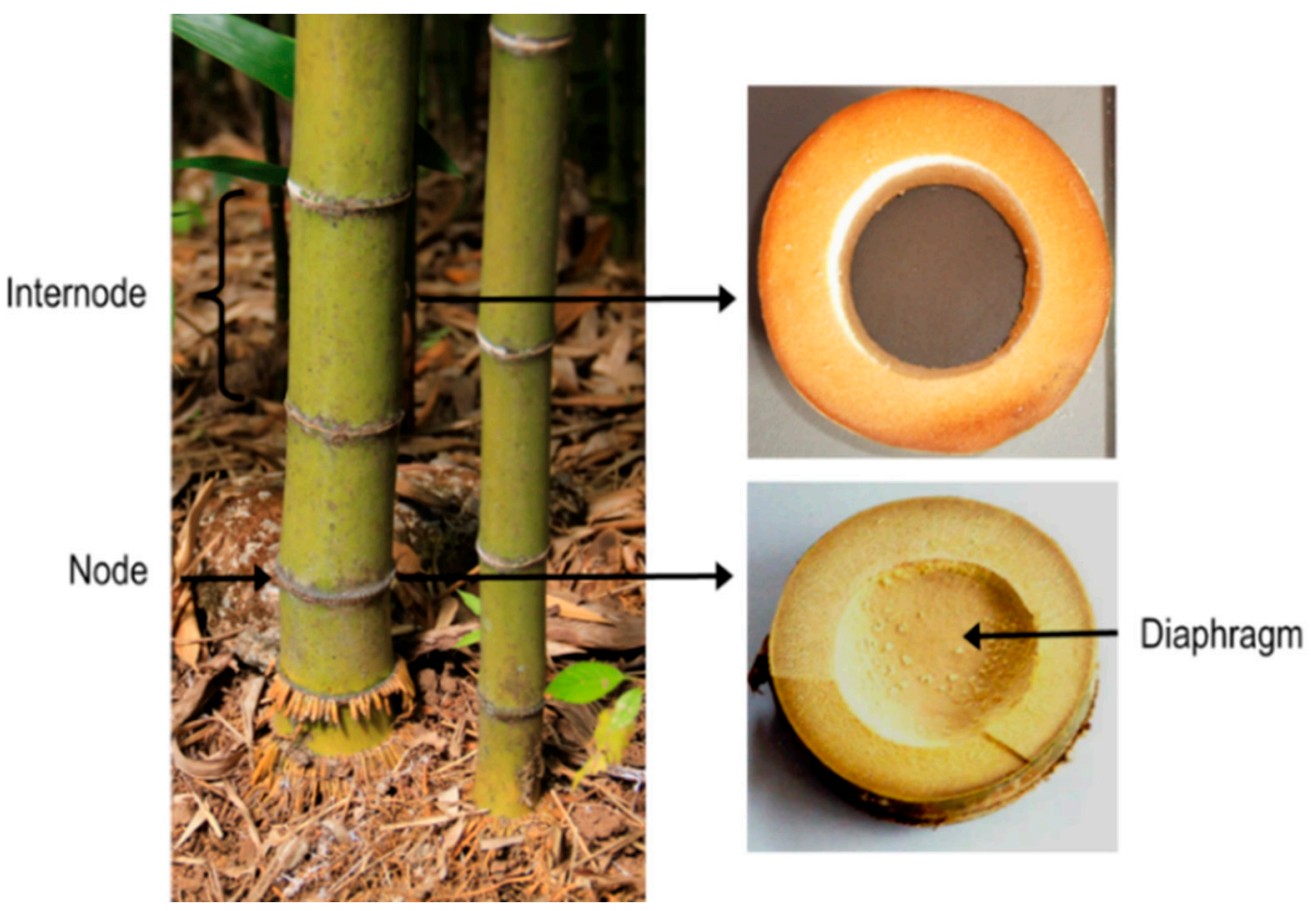

Figure 3. Characteristics of bamboo culm.

The internode is hollow inside, which forms the bamboo cavities. However, some bamboo species have a small hollow part with a thicken culm wall or is almost solid in the lower portion of the culm, as shown in Figure 4. In the internode part, the cells are vertically oriented. The node is a horizontal wooden partition that is located between two adjacent internodes. In the node part, the cells are oriented in the horizontal direction of the culm. The difference of cell orientation in the internode and node parts has the primary effect on culm strength.

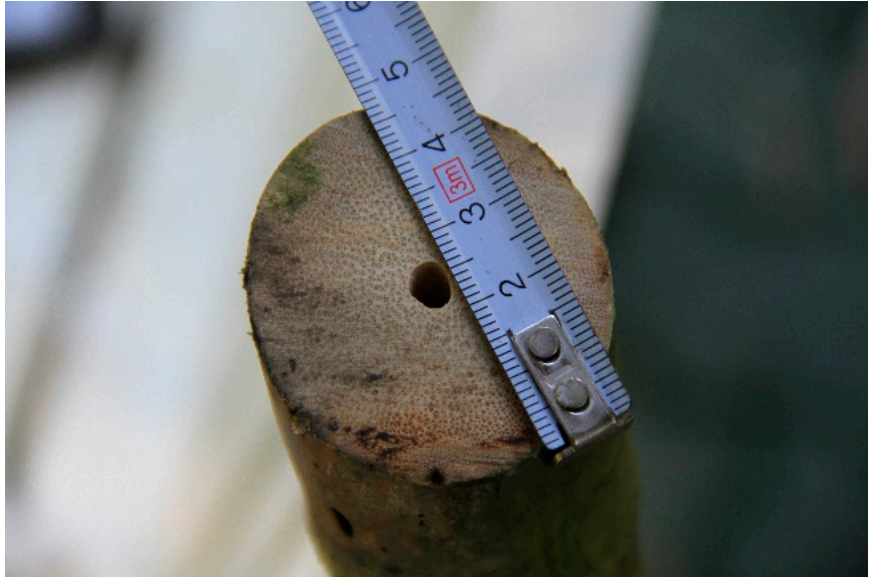

(a)

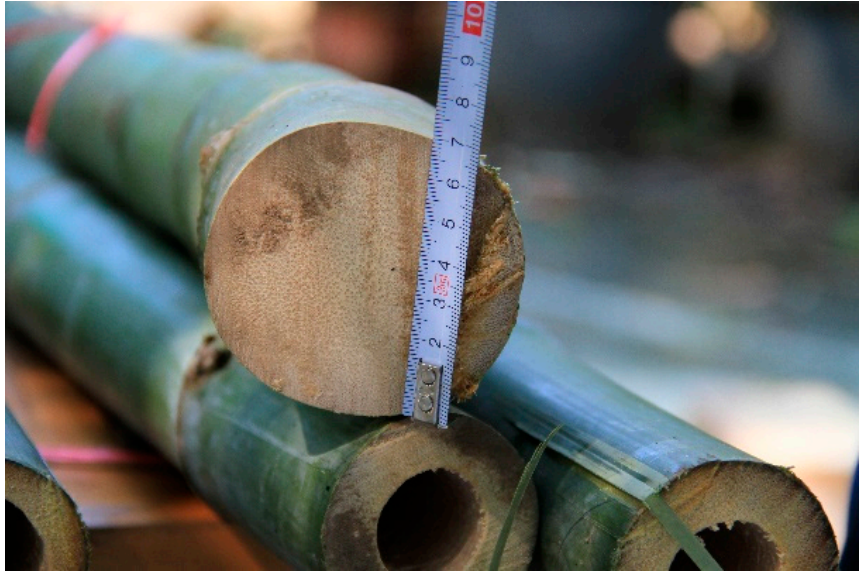

(b)

Figure 4. The thick-walled to solid lower portion of the bamboo culm: (a) T. oliveri and (b) D. sericeus.

Figure 5 shows the selected culm characteristics (internode length, outer culm diameter, and culm wall thickness) of five bamboo species which vary along the length. The results show that the internode length increased from the bottom to the middle part and decreased towards the top. The bamboo culm tapered towards the top with a decrease in the outer culm diameter. The culm wall thickness decreased from the bottom to the top part of the culm. The results also indicate that the culm characteristics (internode length, outer culm diameter, and culm wall thickness) varied between bamboo species. The culm of $D$. 
asper showed the greatest characteristics with the longest internode length, largest culm diameter, and biggest culm wall thickness. The culm of $D$. membranaceus was columnar, only tapering near the top part.

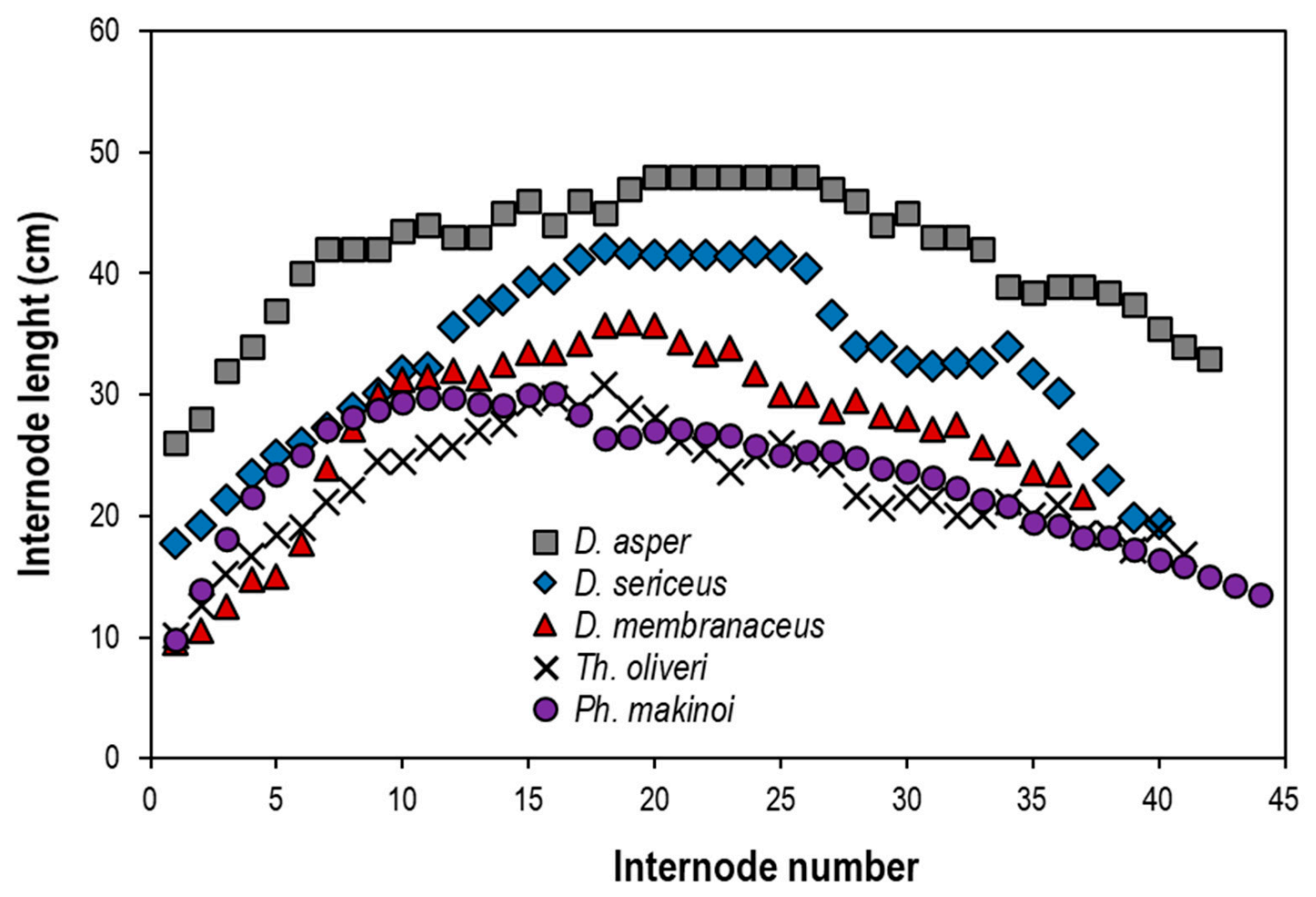

(a)

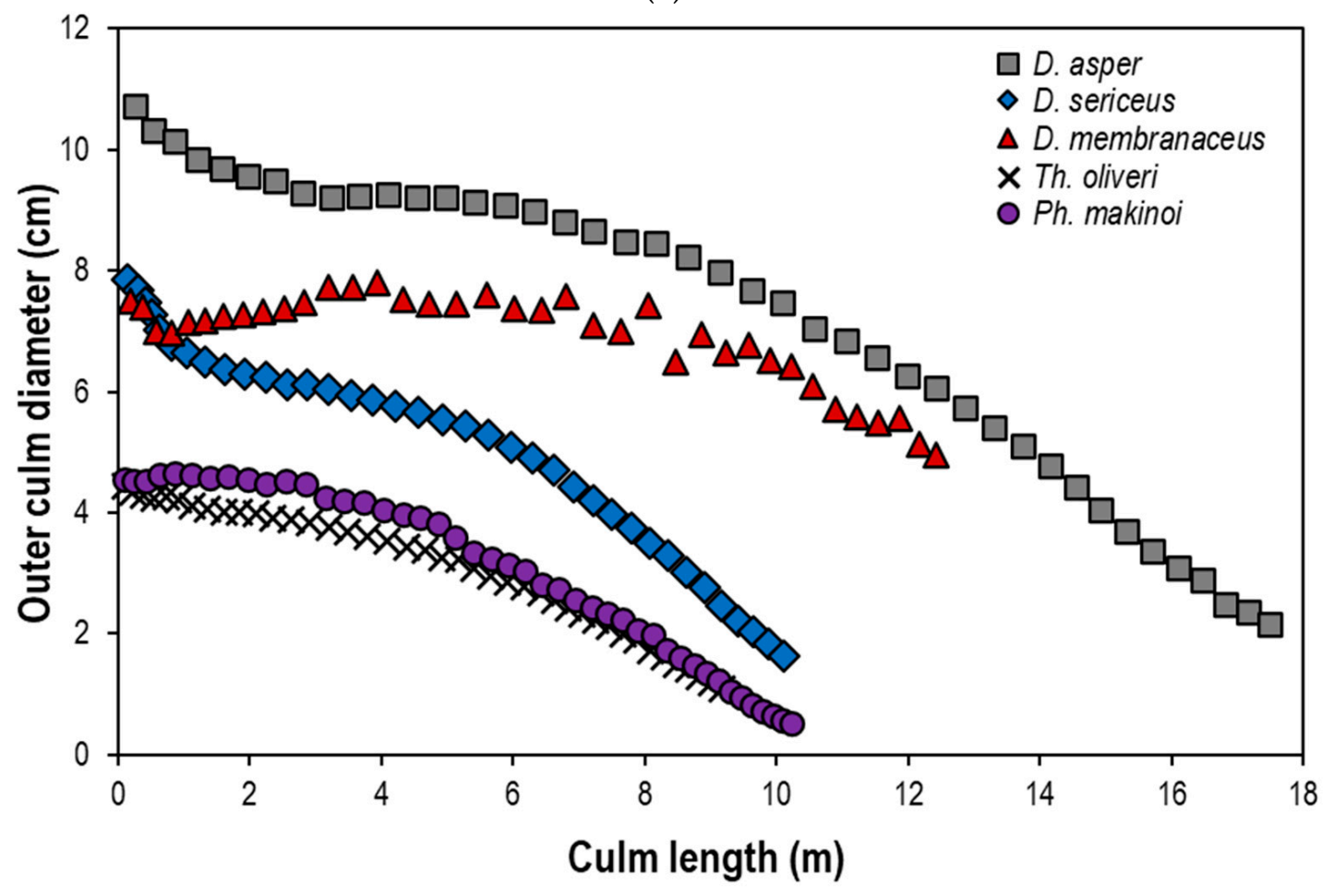

(b)

Figure 5. Cont. 


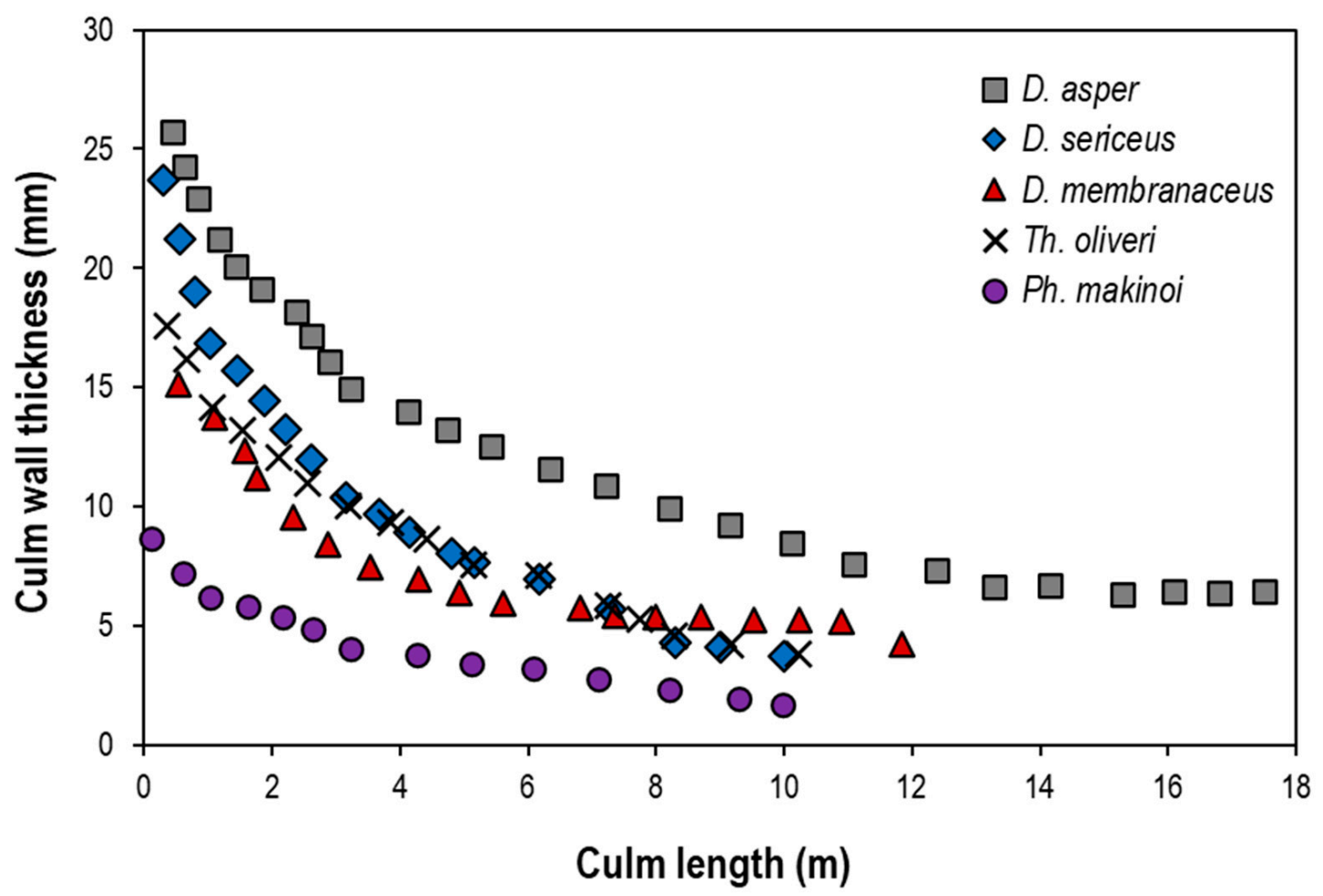

(c)

Figure 5. Variations of culm characteristics along the culm length of five bamboo species: (a) internode length, (b) outer culm diameter, and (c) culm wall thickness.

Compared with wood species, the diameter of the bamboo culm was smaller than the wood log. The diameter of wood logs can reach $1 \mathrm{~m}$; a small diameter is approximately $15 \mathrm{~cm}$. The largest diameter of the bamboo culm (D. asper) tested in this research was only $10 \mathrm{~cm}$, as presented in Figure $5 \mathrm{~b}$. However, the diameter of some big sympodial bamboo species (D. giganteus) reaches $20-30 \mathrm{~cm}$ [5]. D. giganteus is a giant tropical and subtropical clumping bamboo species that is widely distributed in Myanmar, Bhutan, China, and Thailand. It is considered the biggest bamboo in the world.

The characteristics of the bamboo culm are the main parameters that affect bamboo utilization as a building material. The internode length should be considered when bamboo is used for products that involve bamboo slivers or thin strips. The slivers produced from long internode bamboo species give the products a beautiful, smooth, and uniform surface. On the other hand, bamboo species with shorter internode lengths are preferred when the culms are used as structural load-bearing parts, such as columns, posts, or beams. Since nodes act as imposing connectors, a higher number of nodes give the bamboo greater strength. The culm diameter is one of the most important parameters when bamboo is used in its cylindrical form or processed into products. The culm diameter determines the bamboo usage, for example, as columns, posts, bridges, flattened bamboo strips, and glued laminated bamboo. The culm wall thickness of bamboo ranges from $5 \mathrm{~mm}$ to more than $2 \mathrm{~cm}$ depending on the bamboo species and culm location. When producing strips and joineries, thicker-walled bamboo species are preferable. Solid culm bamboos such as $D$. sericeus and T. oliveri have a thick wall with visible nodes. They tend to be more prone to bending than being straight. Because of those characteristics, solid culm bamboos are used for construction, furniture, and household products.

The lack of uniform culm dimensions and culm straightness shows trouble with keeping the culms in line. These features have the primary effect when bamboo culms are used for structural building (particularly trusses). Specific skilled labor and techniques are required to keep the purlins level enough to receive the roof sheets. 


\subsection{The Physical and Mechanical Properties of Bamboo Culms}

The use of bamboo culm as a building material is dependent upon its physical and mechanical properties. Therefore, it is necessary to understand them thoroughly for the successful utilization of bamboo.

\subsubsection{Moisture Content}

Moisture content is a crucial parameter that affects the mechanical properties of wooden material. The required moisture content of wood and lumber as a building material is in the range of $6 \%$ to $8 \%$ for interior use and $9 \%$ to $14 \%$ for exterior wood or for building envelope components within constructed assemblies [8].

Bamboo is a hygroscopic material that can gain or lose water to equilibrate with its environment. The moisture content or equilibrium moisture content of the bamboo species was determined after being conditioned under $27^{\circ} \mathrm{C}$ and $70 \%$ relative humidity. Table 1 illustrates the moisture content of the five bamboo species, ranging from $8.40 \%$ to $13.44 \%$. The moisture content of the internode part is slightly higher than that of the node part. This phenomenon can be explained by the significant difference in the chemical composition and microstructure between the bamboo species and the culm part $[9,10]$.

Table 1. Physical and mechanical properties of bamboo culms.

\begin{tabular}{|c|c|c|c|c|c|c|}
\hline Culm Properties & $n^{*}$ & D. asper & D. sericeus & D. membranaceus & T. oliveri & P. makinoi \\
\hline \multicolumn{7}{|l|}{ Moisture content (\%) } \\
\hline Internode & 30 & $\begin{array}{c}11.52 \\
(0.59)^{* *}\end{array}$ & $\begin{array}{l}11.95 \\
(0.49)\end{array}$ & $\begin{array}{c}9.99 \\
(0.28)\end{array}$ & $\begin{array}{l}13.44 \\
(0.34)\end{array}$ & $\begin{array}{c}8.46 \\
(0.44)\end{array}$ \\
\hline Node & 30 & $\begin{array}{l}10.24 \\
(0.17)\end{array}$ & $\begin{array}{l}11.81 \\
(0.28)\end{array}$ & $\begin{array}{c}9.95 \\
(0.95)\end{array}$ & $\begin{array}{l}13.19 \\
(0.32)\end{array}$ & $\begin{array}{c}8.40 \\
(0.77)\end{array}$ \\
\hline \multicolumn{7}{|l|}{ Density $\left(\mathrm{kg} / \mathrm{m}^{3}\right)$} \\
\hline Internode & 30 & $\begin{array}{l}602 \\
(39)\end{array}$ & $\begin{array}{l}594 \\
(99)\end{array}$ & $\begin{array}{l}712 \\
(54)\end{array}$ & $\begin{array}{l}724 \\
(40)\end{array}$ & $\begin{array}{l}983 \\
(60)\end{array}$ \\
\hline Node & 30 & $\begin{array}{l}596 \\
(40)\end{array}$ & $\begin{array}{l}586 \\
(76)\end{array}$ & $\begin{array}{l}620 \\
(46)\end{array}$ & $\begin{array}{l}706 \\
(84)\end{array}$ & $\begin{array}{l}829 \\
(90)\end{array}$ \\
\hline \multicolumn{7}{|l|}{ Shear strength parallel to grain (MPa) } \\
\hline Internode & 20 & $\begin{array}{l}13.9 \\
(2.1)\end{array}$ & $\begin{array}{l}26.8 \\
(4.9)\end{array}$ & $\begin{array}{l}13.0 \\
(1.7)\end{array}$ & $\begin{array}{l}27.6 \\
(5.1)\end{array}$ & $\begin{array}{l}32.4 \\
(7.0)\end{array}$ \\
\hline Node & 20 & $\begin{array}{l}15.2 \\
(1.4)\end{array}$ & $\begin{array}{l}34.6 \\
(5.8)\end{array}$ & $\begin{array}{l}16.8 \\
(2.1)\end{array}$ & $\begin{array}{l}31.0 \\
(4.0)\end{array}$ & $\begin{array}{c}50.2 \\
(50.2)\end{array}$ \\
\hline \multicolumn{7}{|l|}{ Tensile strength parallel to grain (MPa) } \\
\hline Internode & 20 & $\begin{array}{l}168 \\
(29)\end{array}$ & $\begin{array}{l}120 \\
(31)\end{array}$ & $\begin{array}{l}195 \\
(30)\end{array}$ & $\begin{array}{l}144 \\
(35)\end{array}$ & $\begin{array}{l}216 \\
(37)\end{array}$ \\
\hline Node & 20 & $\begin{array}{l}72 \\
(25)\end{array}$ & $\begin{array}{l}71 \\
(23)\end{array}$ & $\begin{array}{c}82 \\
(27)\end{array}$ & $\begin{array}{c}95 \\
(27)\end{array}$ & $\begin{array}{l}146 \\
(21)\end{array}$ \\
\hline $\begin{array}{l}\text { Compressive strength parallel to grain } \\
\qquad(\mathrm{MPa})\end{array}$ & 30 & $\begin{array}{l}56.0 \\
(7.5) \\
\end{array}$ & $\begin{array}{l}58.1 \\
(5.7) \\
\end{array}$ & $\begin{array}{l}80.2 \\
(9.9) \\
\end{array}$ & $\begin{array}{l}64.8 \\
(5.5) \\
\end{array}$ & $\begin{array}{c}102.9 \\
(9.0) \\
\end{array}$ \\
\hline Modulus of rupture (MPa) & 20 & $\begin{array}{l}58.4 \\
(9.2) \\
\end{array}$ & $\begin{array}{c}81.1 \\
(19.0) \\
\end{array}$ & $\begin{array}{c}29.3 \\
(10.7) \\
\end{array}$ & $\begin{array}{c}68.6 \\
(16.7) \\
\end{array}$ & $\begin{array}{c}81.4 \\
(19.0) \\
\end{array}$ \\
\hline Modulus of elasticity (MPa) & 20 & $\begin{array}{l}1190 \\
(693)\end{array}$ & $\begin{array}{l}3985 \\
(788)\end{array}$ & $\begin{array}{l}1306 \\
(699)\end{array}$ & $\begin{array}{l}3749 \\
(506)\end{array}$ & $\begin{array}{l}4134 \\
(701)\end{array}$ \\
\hline
\end{tabular}

Note: ${ }^{*}$ Number of replications. ${ }^{* *}$ Numbers in parenthesis are standard deviation values.

The results also suggest that bamboo samples that were conditioned under $27^{\circ} \mathrm{C}$ and $70 \%$ relative humidity were not attached with fungi. Based on previous studies [11], bamboo deterioration by fungi appeared when the moisture content was above $15 \%$. 


\subsubsection{Density}

The density value of the bamboo specimens ranged from $594-933 \mathrm{~kg} / \mathrm{m}^{3}$, depending mainly on the bamboo species, and culm part. P. makinoi showed the highest value, while $D$. sericeus showed the lowest value. On average, the internode part showed a slightly higher density than that of the node part. This finding is also in agreement with Huang et al. [12], who reported that the density of specimens with nodes and specimens without nodes were different. This variation is caused by the distinctive characteristic of vascular bundles in nodes showing less content of a vascular bundle, shorter fiber length, and wider lumen diameter of parenchyma cells compared to internodes [13]. Compared to hardwood species used for construction in Thailand, such as Dalbergia latifolia, Shorea spp., and Tectona grandis [14], the bamboo showed a higher density. Moreover, the results indicate that bamboo density varies along with the culm location. As presented in Figure 6, the density slightly increased from the bottom to top part of the bamboo culm. This result may be explained by the increase of fiber cells from the bottom to the top of the culm [15]. Generally, bamboo culms have higher fiber content at the top parts where the fibers are closely packed, as shown by other studies on the microstructure of bamboo culm [16-18]. Many studies have been published on the correlation between the density and strengths of bamboo [16-19]. They reported that the bending strength and compressive strength of bamboo increased when the density increased. Due to the uneven distribution of specific gravity with different heights and positions of the bamboo culm, it is expected that these features may affect the application of the bamboo culm.

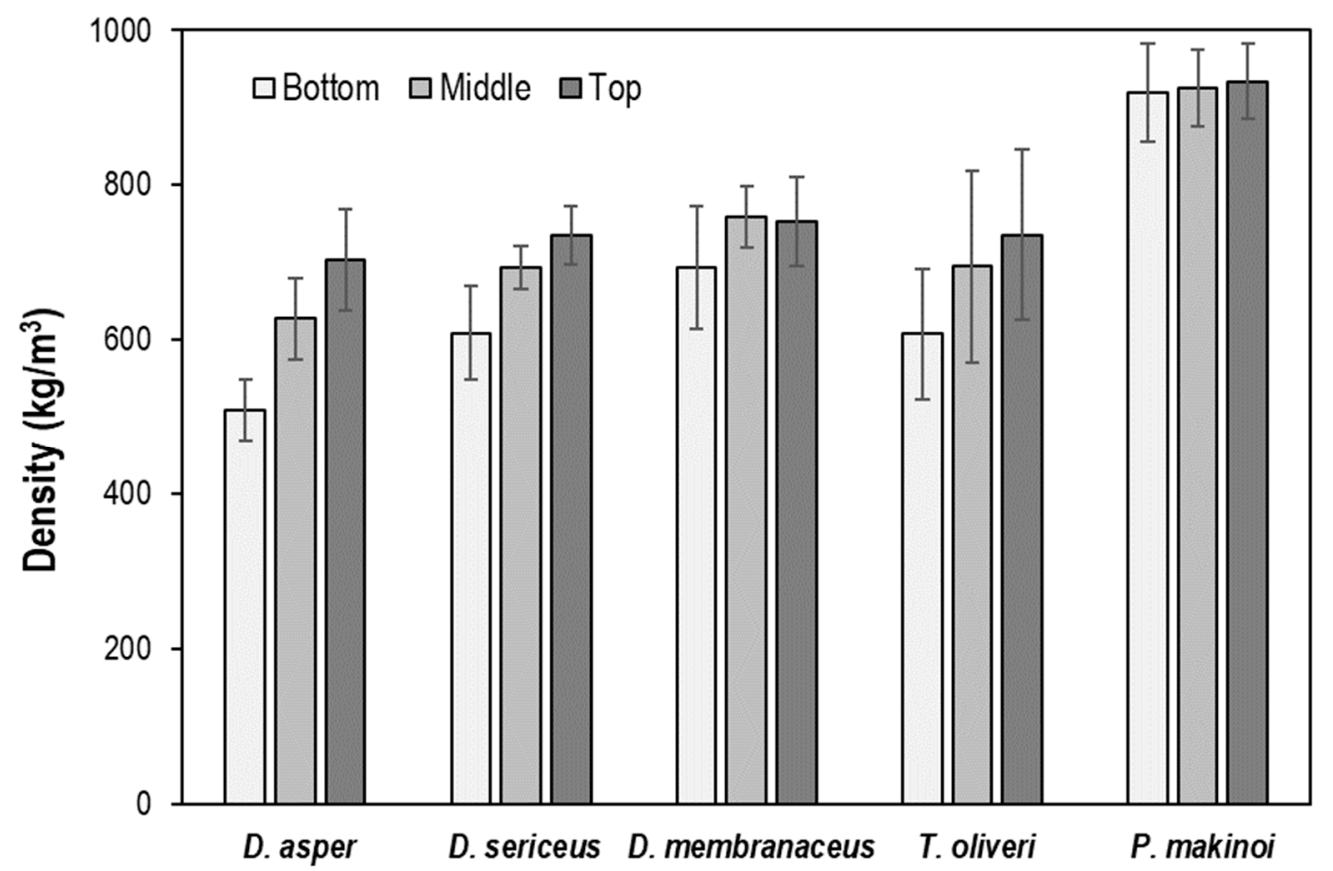

Figure 6. The variation in density concerning the portion of the bamboo culm.

\subsubsection{Shear Strength Parallel to Grain}

A summary of shear strength parallel to the grain for the bamboo culms is given in Table 1. P. makinoi showed the highest shear strength for both the node and internode parts. A comparison of shear strength parallel to the grain of the bamboo to those of other hardwood species used as raw material for construction in Thailand as mentioned before [14] showed that the bamboo had higher shear strength than the hardwood.

The results also suggest that the specimens with nodes showed higher shear strength than the specimens without nodes. One possible explanation might rest on the transverse orientation of cells in the node part. The horizontal orientation of cells through the diaphragm can resist more ultimate load resulting in higher shear strength $[20,21]$. Figure 7 presents the failure mode of a bamboo specimen. In most cases, the shear failure ruptured 
along the entire specimen length even though each specimen did not possess a similar ultimate load and shear stress. Based on visual inspection, the specimen without a node failed by splitting, while the specimen with a node did not split off.

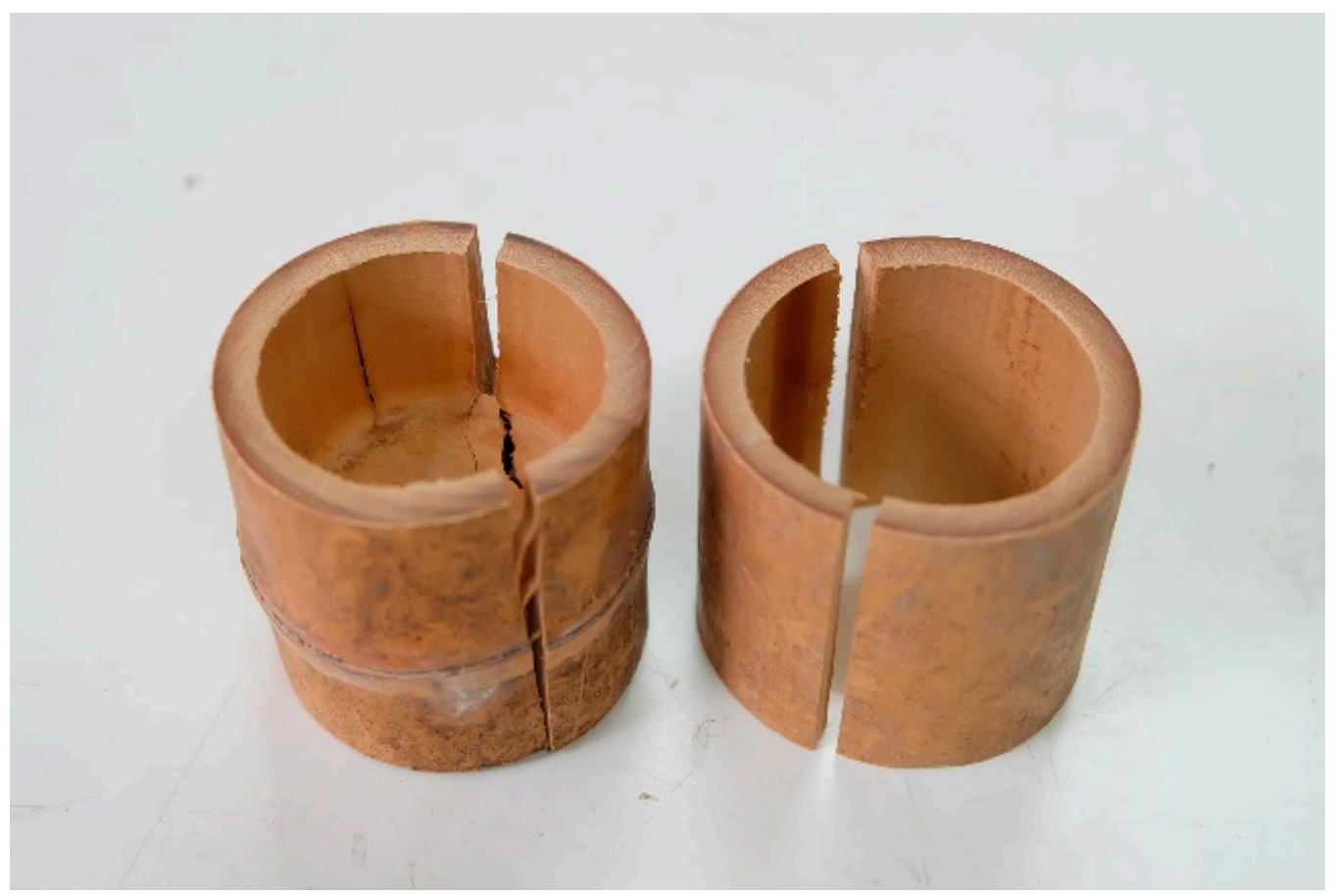

Figure 7. Photograph of a bamboo specimen with a node (left) and without a node (right) after failure in the shear strength parallel to grain test.

The sample of load-deformation curves obtained from the shear strength test is shown in Figure 8. This result suggests that the bamboo sample without a node showed a long linear relationship between the load and deformation in the first stage, followed by ascending non-linear behavior up to a peak load and then a sharp drop in load at failure. The bamboo sample with a node showed the linear relationship between the load and deformation at the beginning, followed by rising non-linear behavior up to a peak load in which the first failure occurred. This failure can be called an initial failure. After the initial failure occurred, the sample still carried an additional load that caused the second failure to occur in the shear plane. The conclusion was drawn that the node positively affected shear strength, resulting in higher shear strength and toughness.

From this point of view, shear strength is an important factor used to design joints that connect one bamboo culm with another. Sample fasteners used with bamboo include nails, bolts, pins, steel wires, and other fasteners. When installing joints, a hole is drilled through the bamboo culm and the fastener is put through this hole. During use, the tensile or compressive forces from this fastener occur at the end of the bamboo joint, resulting in shear force. Therefore, the joint should be as close to a node as possible.

In some situations, the low shear strength of bamboo is an advantage for some targets. Bamboo culms can be easily split into thin strips, thin pieces of bamboo with uniform thickness and width for making bamboo mats and glued laminated bamboo. These products are the engineered bamboo composites that have high strength and stiffness. They can also be used as construction material [22]. 


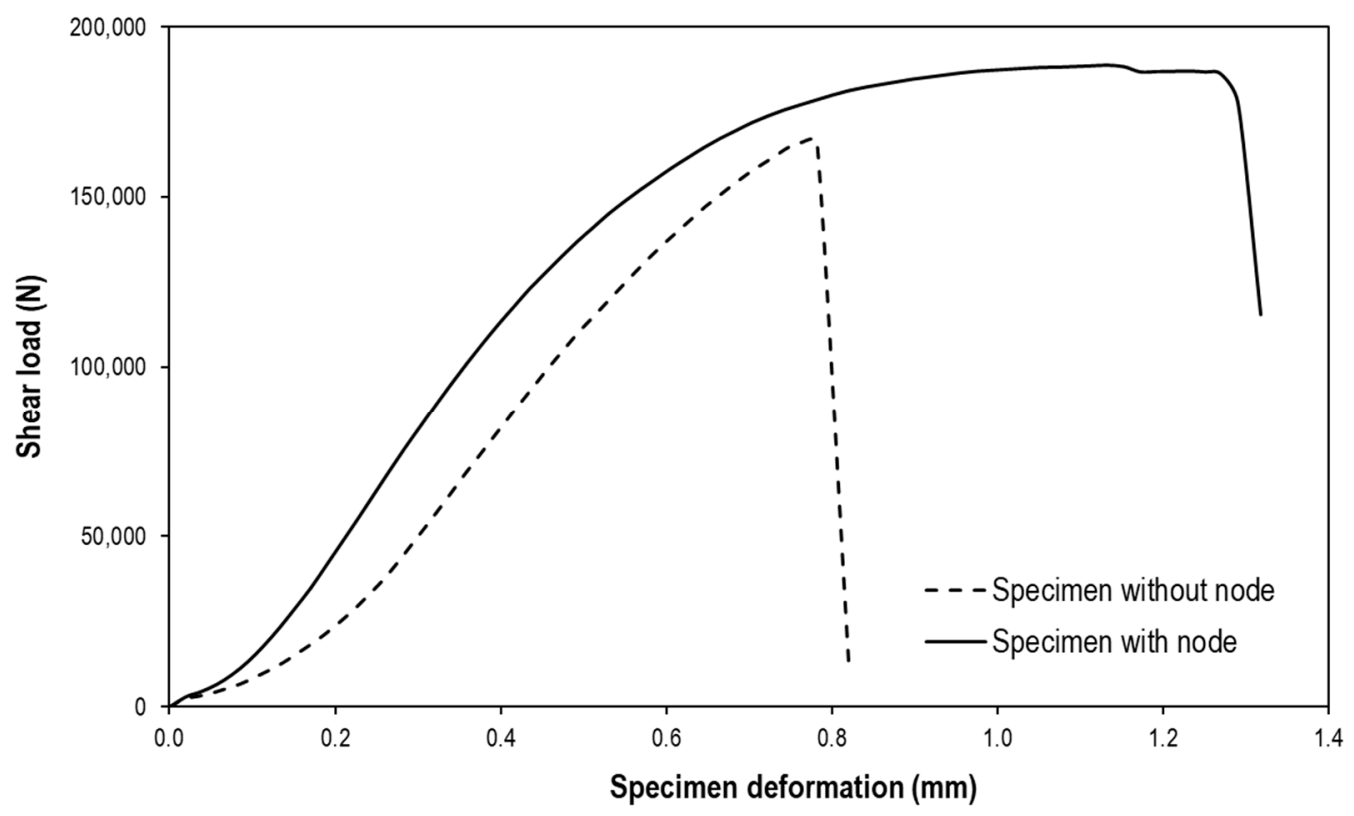

Figure 8. Representative load-deformation curves of a bamboo specimen with an internode and with a node under the shear strength parallel to grain test.

\subsubsection{Tensile Strength Parallel to Grain}

Table 1 shows the tensile strength parallel to the grain of five bamboo species as a function of the culm part. The results demonstrate that $P$. makinoi showed the highest tensile strength for both the node and internode parts. The tensile strength of the specimens with nodes was higher than those without nodes by approximately 1.8 times. This finding is also in agreement with Shao et al. [20], Lee et al. [23], and Srivaro and Jakranod [24]. During testing, it was observed that the specimens with nodes failed at the node part, while the specimens without nodes failed along the gauge length because of the longitudinal splitting of fibers, as shown in Figure 9. The behavior can be explained by the difference of cell orientation in the internode and node parts, as mentioned above.

The representative tensile load versus sample extension data is shown in Figure 10. Both specimens showed only the linear relationship between the load-extension curves before failure and the sharp drop in load at failure. The non-linear relationship was absent because the failure was caused by the fiber rupture. It could be concluded that the presence of the node part in the bamboo culm had a disadvantage on the tensile strength parallel to the grain.

This research revealed that bamboo strips possess excellent tensile strength, which is relatively high and can reach 150-200 MPa. Moreover, bamboo is a lightweight material. The ratio between the tensile strength and specific weight of bamboo is six times greater than steel. Therefore, bamboo strips can be used as a substitute for steel reinforcement in reinforced concrete beams, floors, or columns. However, the bonding between bamboo strips and concrete is critical when bamboo strips are used as concrete reinforcement. When concrete is poured into the forming box, the bamboo strips absorb water and swell. During the hardening process, the concrete hardens and dries, and the bamboo strips also dry and shrink. Since bamboo shrinks more than concrete, these voids ultimately break down the bonding between the bamboo strips and concrete. Many researchers have suggested solving this problem by coating bamboo strips with moisture protection substances such as bitumen, wax, epoxy, or polyvinyl to improve sufficient bonding with the concrete matrix $[25,26]$. 


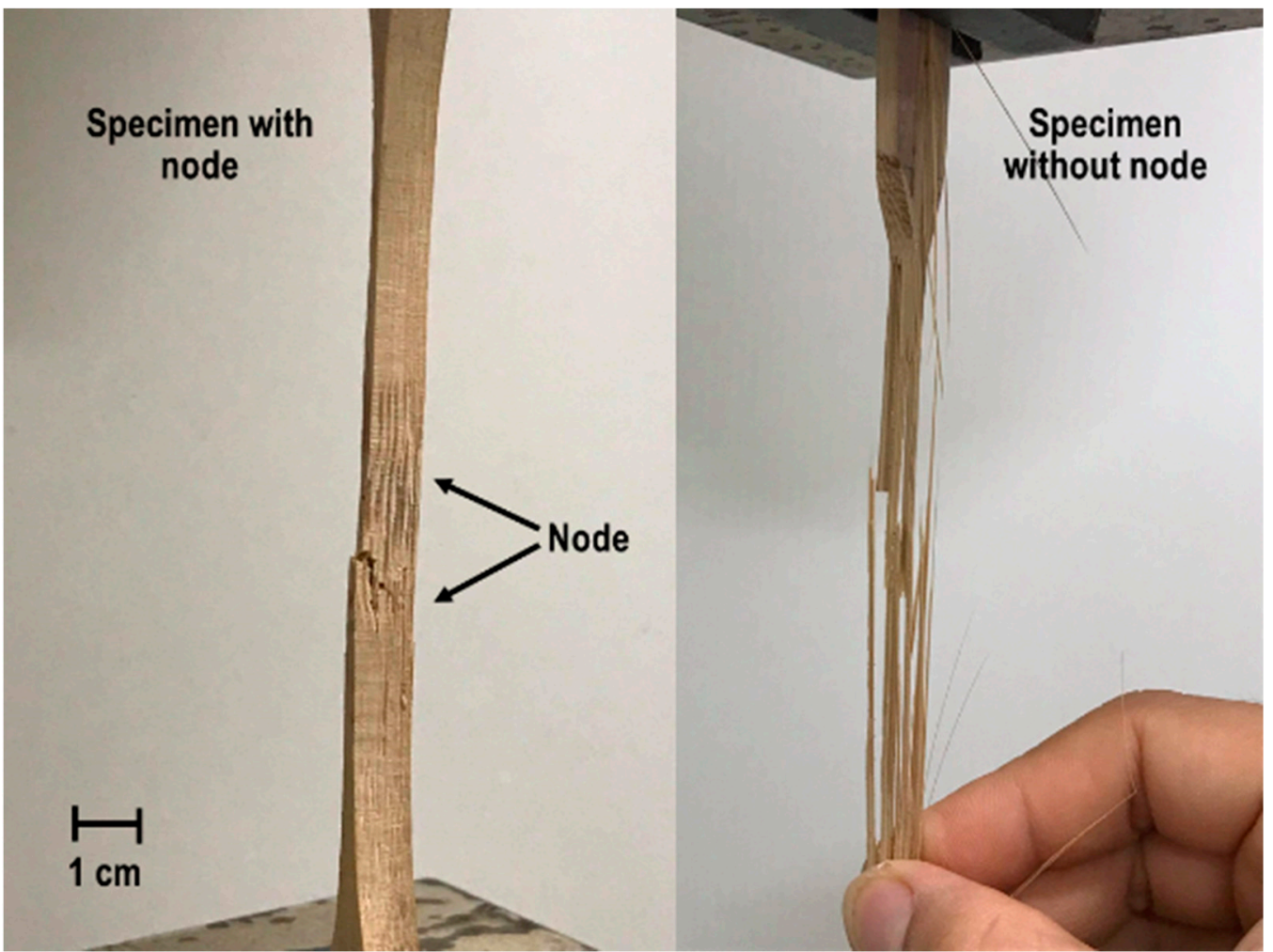

Figure 9. Fracture of a specimen with a node and without a node after the tensile strength parallel to grain test.

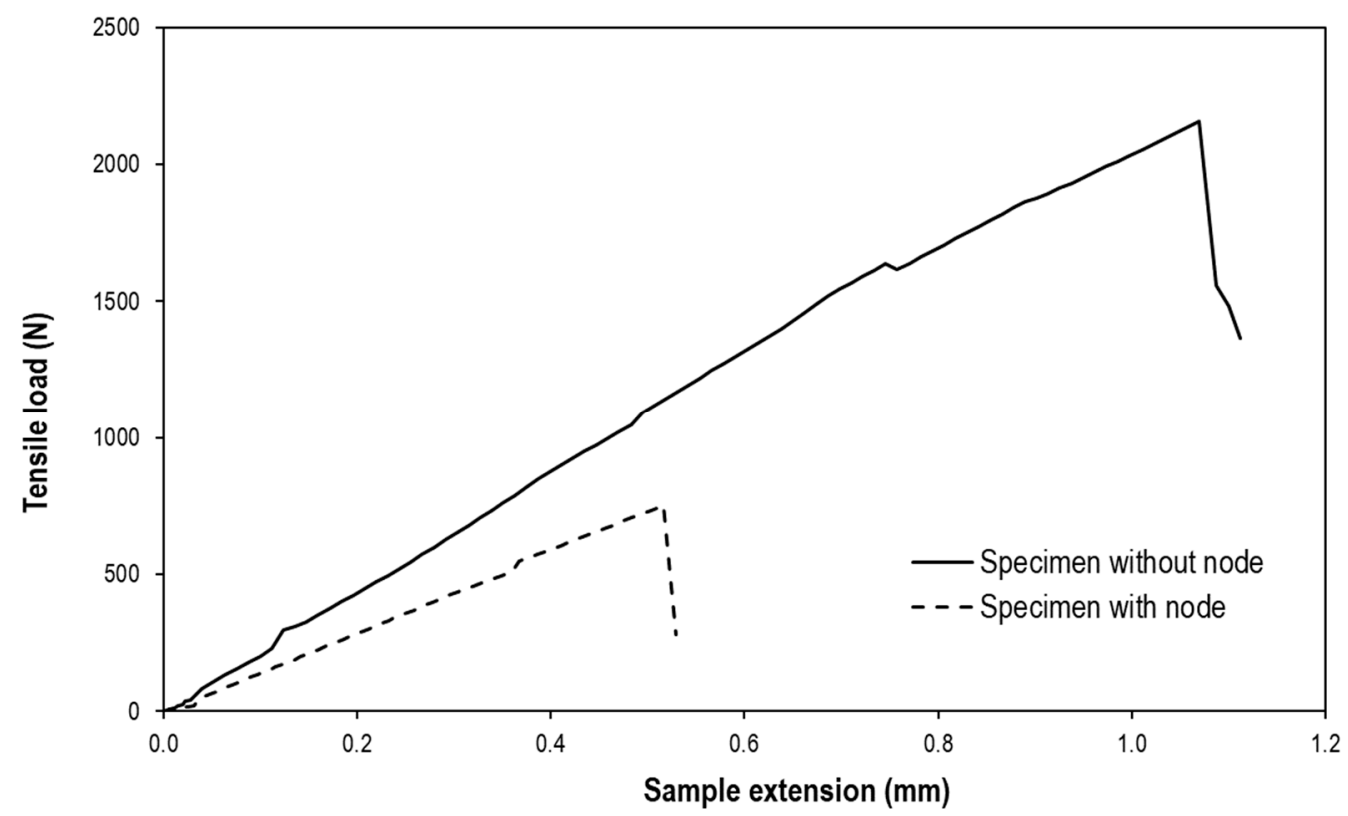

Figure 10. Typical load versus extension curves of a specimen without a node and with a node for the tensile strength parallel to grain test.

\subsubsection{Compressive Strength Parallel to Grain}

The compressive strength parallel to the grain of the five bamboo species is illustrated in Table 1. The results illustrate that $P$. makinoi showed the highest compressive strength, while $D$. asper showed the lowest compressive strength. The effects of density could be explained in this situation. When the density increased, the compressive strength also increased, as illustrated in Figure 11. 


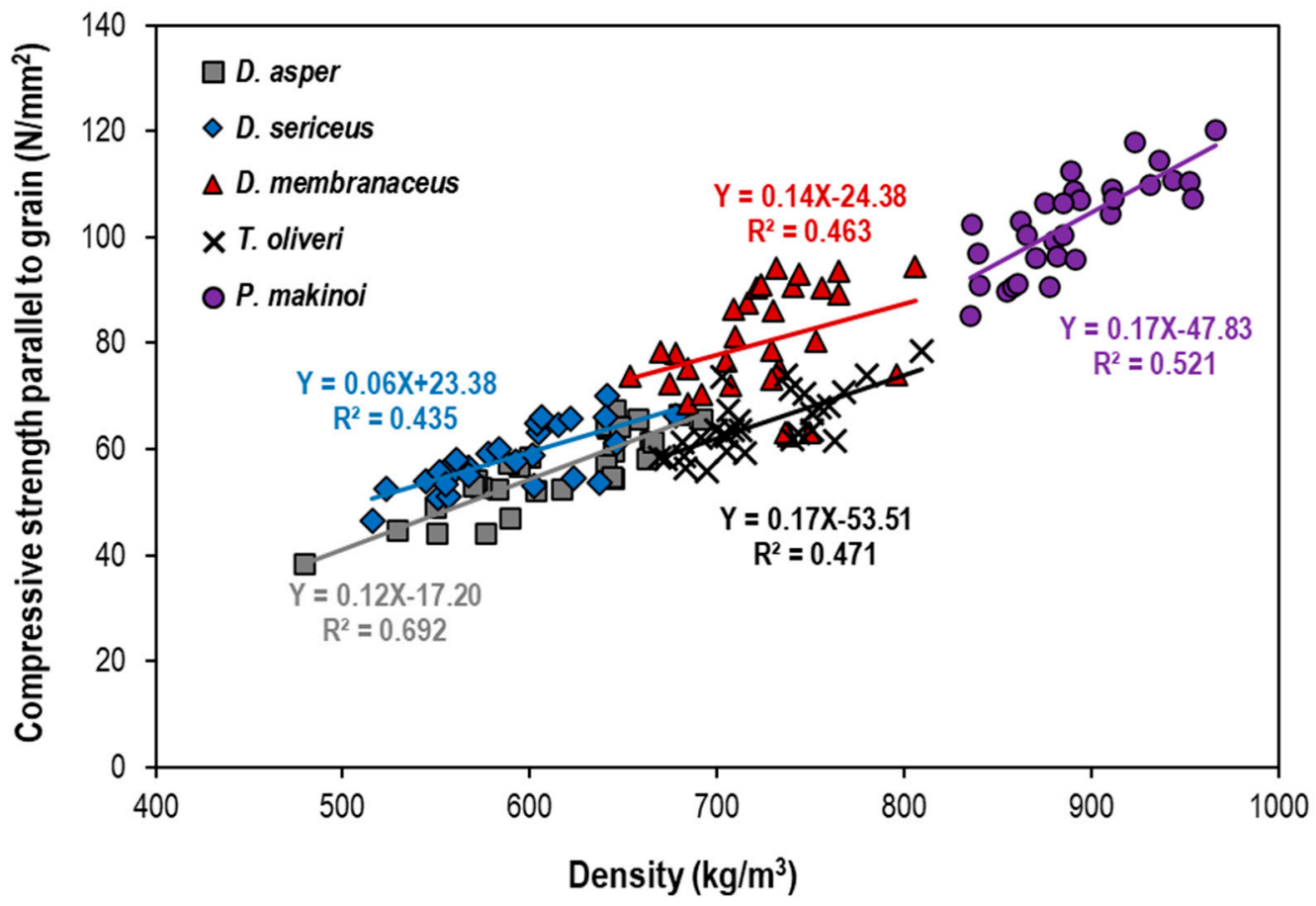

Figure 11. Relationship between the density and compressive strength parallel to the grain of the five bamboo species.

The results suggest that there was a variation in the compressive strength along the culm length. Considering the bamboo culm characteristics illustrated above, the culm diameter and culm wall thickness decreased with the culm length, reducing the crosssection area over which the stress was determined. Hence, the bottom portion of the culm having a bigger culm diameter and thicker culm wall resulted in the greater cross-section area of the specimen compared to the middle and top portions. Therefore, the bottom portion of the culm can carry more ultimate load than the middle and top portions, as presented in Figure 12.

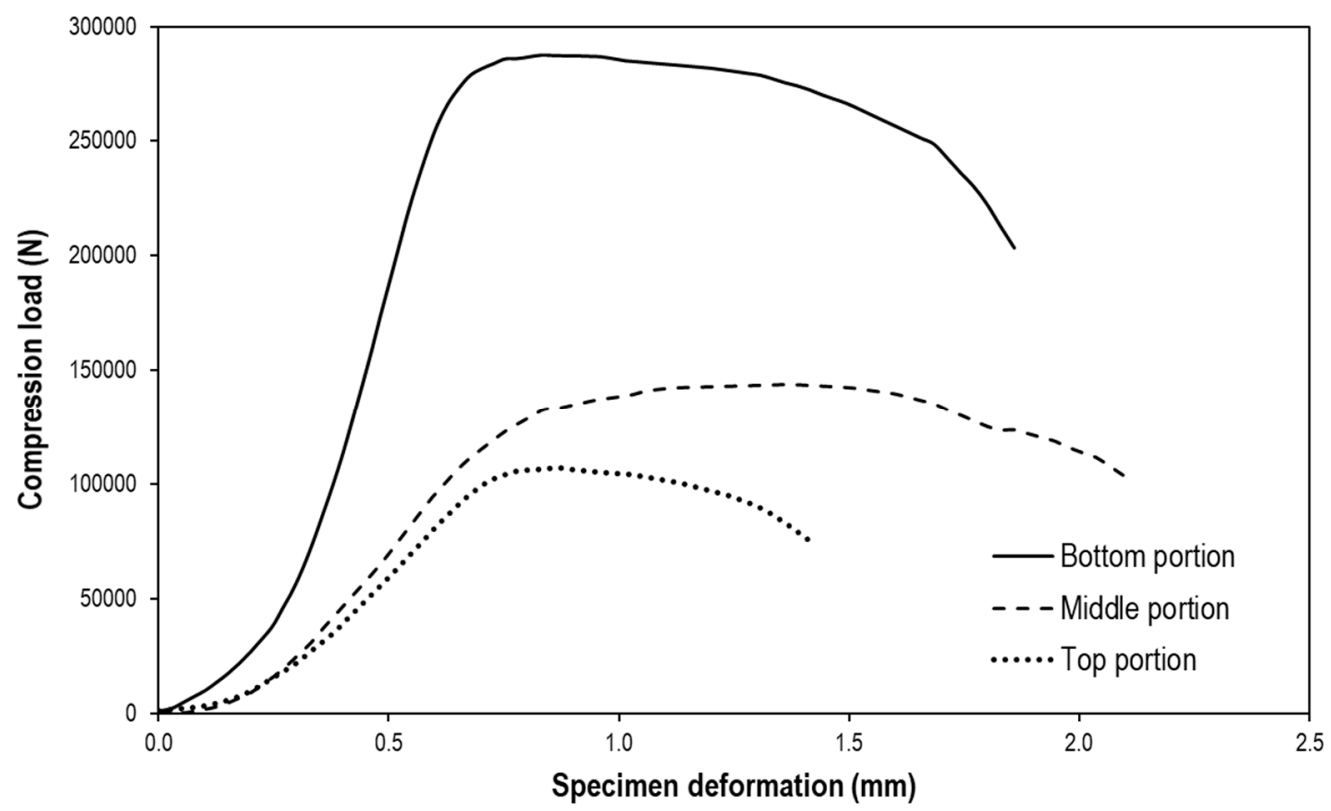

Figure 12. Representative compression load vs. specimen deformation curves of the specimens from the bottom, middle, and top portions of the bamboo culm for the compressive strength parallel to grain test. 
Representative graphs of the compression load versus specimen deformation relationship of the specimens from the bottom, middle and top parts of the bamboo culm for the compressive strength parallel to grain test are shown in Figure 12. Three phases can be distinguished in this study: (Phase 1) the initial non-linear deformation, resulting from uneven loading through the culm end, at the low load level and following the strengthening curve; (Phase 2) the linear load-deformation relationship; and (Phase 3) the non-linear and ductile load-deformation relationship leading to failure. During the compression test, the culm became axial larger in the middle part when the load reached the maximum. Therefore, the specimen split and ruptured, as presented in Figure 13. Once split, the slope of the compression load-deformation curve turned negligible.

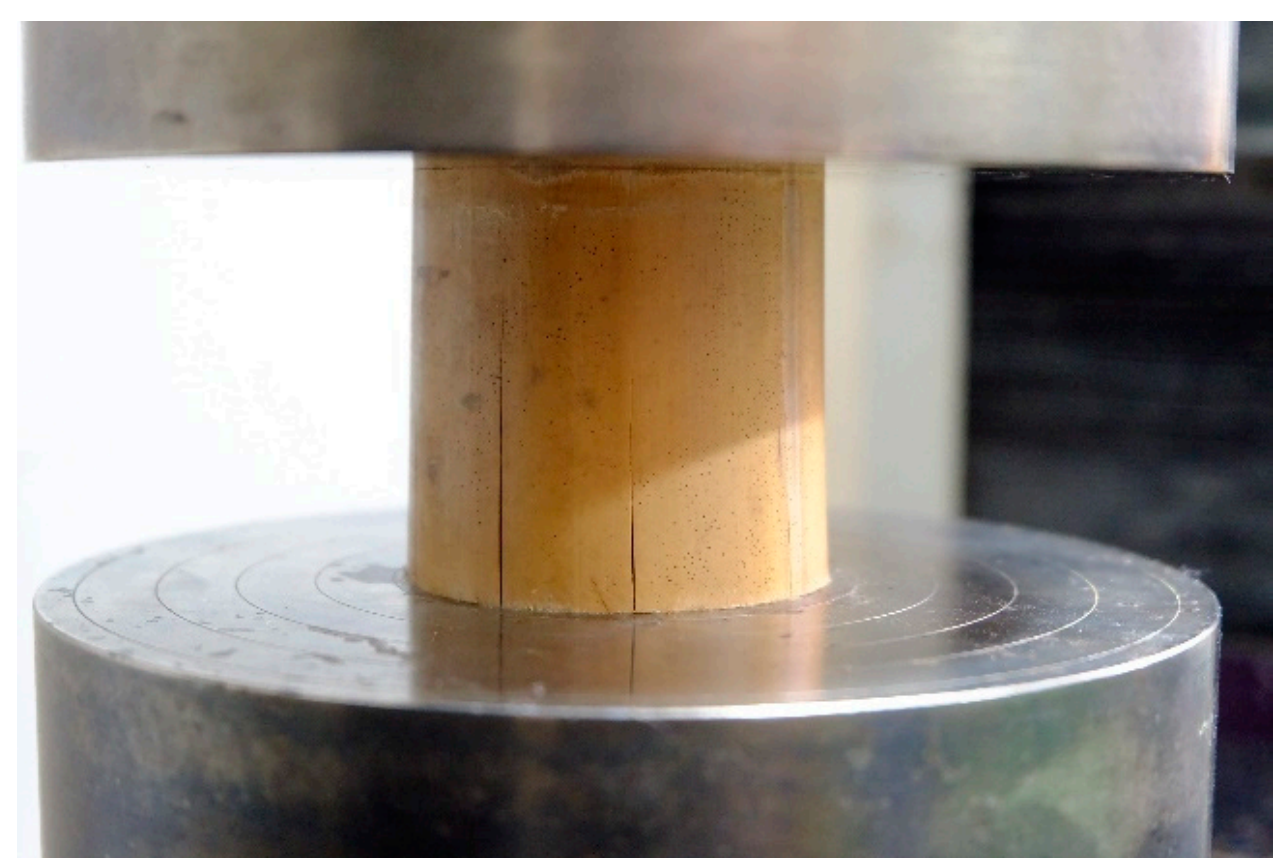

Figure 13. The splitting failure mode of a bamboo specimen after the compression strength test.

Compared to the hardwood tropical timber species which are typically used in construction as mentioned above [14], the compressive strength parallel to the grain of the bamboo was in the same range.

Columns are the members of structures that receive compression load. The compressive strength of bamboo culms should be considered when it is designed to be columns. This study demonstrated that the ultimate load depended on the size of the column. For strength and stability, the bottom part of the bamboo culm with a large diameter, thick wall section, and closely spaced nodes should be used. In practice, this part can receive more ultimate load and be used as a strong column. However, small diameter culms tied together with rope and steel bands can be used as a bamboo composite column. It should be noted that the culm size should be considered when bamboo culms are used as columns.

\subsubsection{Bending Strength}

The average MOR and MOE values of the bamboo culms in the four-point bending test are presented in Table 1. The results show that P. Makinoi showed the highest MOR and MOE values, while D. membranaceus showed the lowest MOR value and D. asper showed the lowest MOE value.

The results also reveal that culm sizes, especially the culm diameter and culm wall thickness, affected the ultimate load. Figure 14 illustrates the load-deflection diagrams of the bamboo culms (bottom, middle, and top portions) tested on the four-point bending test. As expected, the bottom portion of the bamboo culm with a bigger culm diameter and 
thicker culm wall can carry more bending load than the middle and top portions with a smaller culm diameter and thinner culm wall.

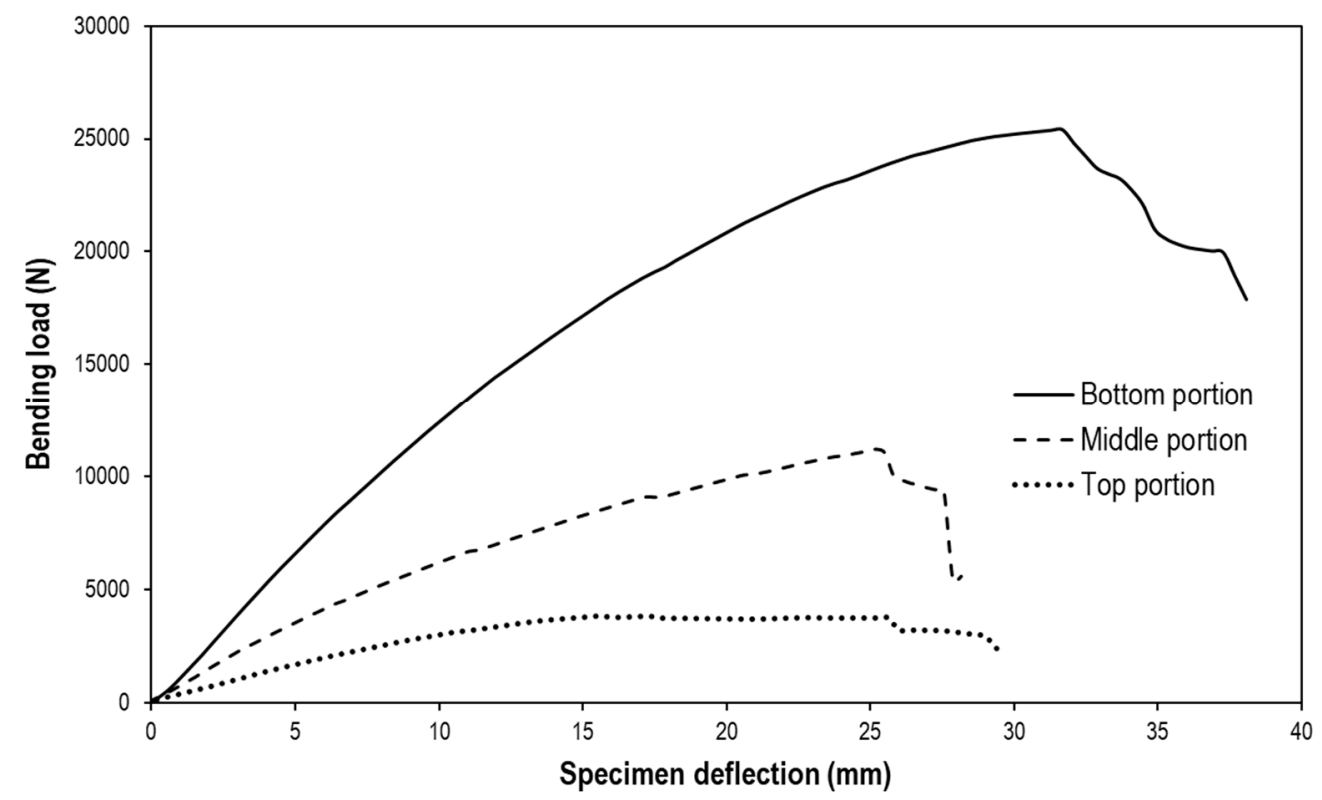

Figure 14. Selected load-deflection diagrams from the four-point bending test for each part of the bamboo culm.

Notably, the failure mode in the bending test did not shatter the bamboo. When the bending load was applied, the sample break developed by longitudinal splitting on the upper part of the sample and the circular shape of the culm changed (Figure 15a). Surprisingly, the bamboo could return to its original straight form after the load was removed (Figure 15b). This behavior can be a specific advantage when a building constructed from bamboo suffers a heavy earthquake or storm. The bamboo building can be left standing with minor damage to the structural members. Some temporary repairs can be done until the damaged parts are replaced.

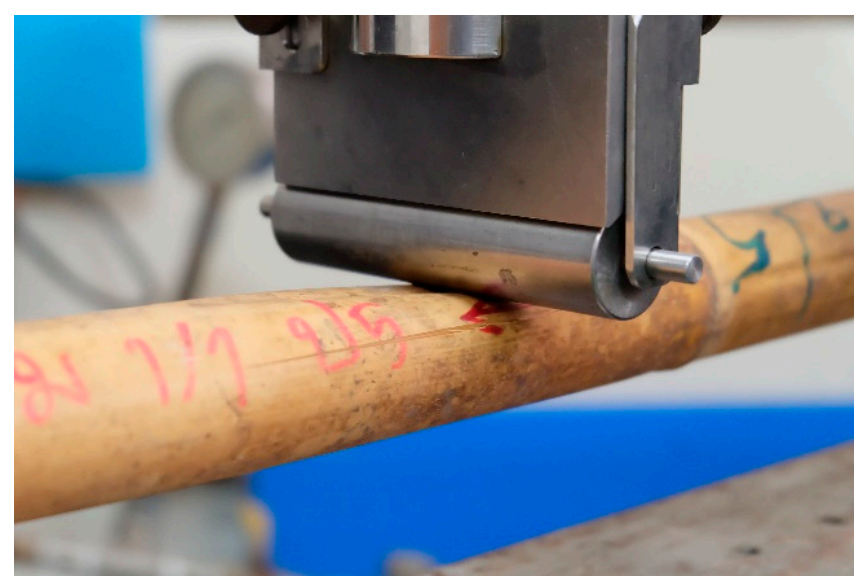

(a)

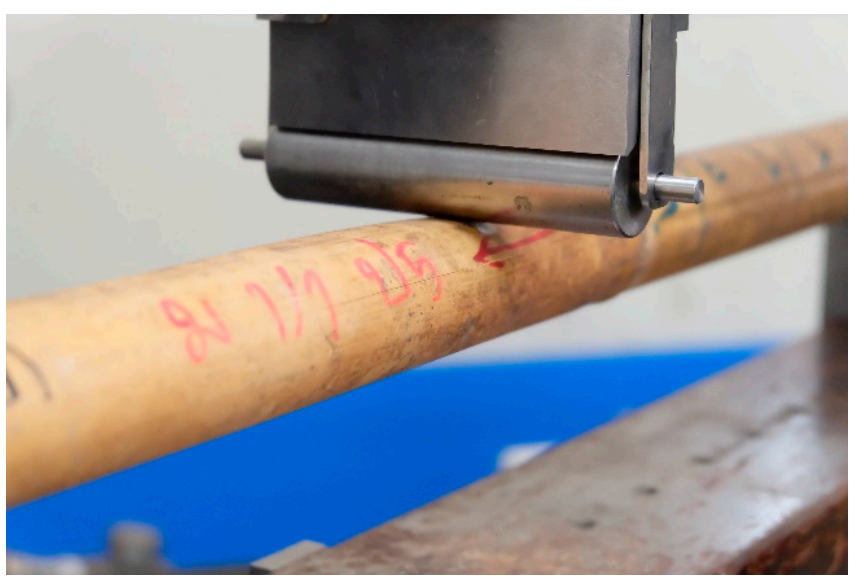

(b)

Figure 15. This phenomenon occurs during the bending test of the bamboo culm, where (a) the failure mode of bamboo specimen and (b) the bamboo specimen returns to its original form after the load is removed.

From this point of view, the bending strength of the building material directly influences the behavior of a structure; it is necessary to know the ultimate load and deflection of each member of a structure before it is built. The roof truss of a building is arguably its most crucial component. It must be strong enough to resist the forces generated by 
the wood and roof covering. In this respect, bamboo culm is ideal as a raw material for roof trusses because it is strong, resilient, and lightweight. Moreover, the truss can be fabricated from the shorter members (counteracting crooked and tapered bamboo culm). This structure highlights the appropriate joint technology and the loading point on the members. The load should be placed on the node part to avoid crushing the internode.

\section{Conclusions}

Understanding the culm characteristics and properties is necessary as bamboo can be used in the construction field. The major purpose of this study was to investigate the culm characteristics and properties of five bamboo species, including the failure behavior of the bamboo specimens. The following conclusions can be drawn from this study:

1. Each bamboo species shows different culm characteristics along the culm length The internode length increases from the bottom to the middle part and decreases towards the top part. Bamboo culm tapers towards the top with a decrease in the outer culm diameter. The culm wall thickness decreases from the bottom to the top part of the culm.

2. The density of the five bamboo species varies from $594-933 \mathrm{~kg} / \mathrm{m}^{3}$. Density significantly increases from the bottom to the top of the culm. Bamboo density affects the strength of bamboo culm. With the increase of density, the strength value also increases.

3. For the five bamboo species, shear strength parallel to the grain varies from 13 to $50.2 \mathrm{MPa}$. Tensile strength parallel to the grain varies from 71 to $216 \mathrm{MPa}$. Compressive strength parallel to the grain varies from 56 to $132.9 \mathrm{Mpa}$. MOR varies from 29.3 to $102 \mathrm{MPa}$, and MOE varies from 1306 to $4134 \mathrm{MPa}$.

4. Based on the mechanical properties, P. makinoi has the highest value in shear, tensile, compressive, and bending strength because of its highest density. However, D. asper can receive the highest ultimate load due to its culm size.

5. Culm diameter and wall thickness affect the received ultimate load. A larger culm diameter with a thicker culm wall can receive more ultimate load.

6. Nodes present along the bamboo culm show higher shear strength parallel to the grain when compared to internodes. However, nodes have a negative effect on tensile strength parallel to the grain. The tensile strength of nodes is lower than that of internodes.

7. From an architectural and engineering point of view, bamboo is recognized as a sustainable building material. Its lightweight and superior physical and mechanical properties have attracted the attention of civil engineers, architects, academics, designers, and artists.

Author Contributions: K.C. contributed to analyzing the results and discussion and writing the manuscript with support from P.C., who carried out the experiment; S.W. also carried out the experiment; P.C. helped supervise the project and conceived the original idea. Moreover, P.C. contributed to the design and implementation of the research. All authors provided critical feedback and helped shape the research, analysis, and manuscript. All authors have read and agreed to the published version of the manuscript.

Funding: This research was funded by the Royal Project Foundation, Thailand, grant number 30353964. The APC was funded by Institute of Research and Innovation, and College of Graduate Studies, Walailak University.

Institutional Review Board Statement: Not applicable.

Informed Consent Statement: Not applicable.

Data Availability Statement: All data are contained within the article.

Acknowledgments: The authors gratefully acknowledge the Royal Project Foundation for the financial support. A special thanks goes to the Center of Excellence on Wood and Biomaterials, Walailak University, for the experimental work. 
Conflicts of Interest: The authors declare that they have no known competing financial interests or personal relationships that could have appeared to influence the work reported in this paper.

\section{References}

1. Canavan, S.; Richardson, D.M.; Visser, V.; Le Roux, J.J.; Vorontsova, M.; Wilson, J.R. The global distribution of bamboos: Assessing correlates of introduction and invasion. AoB Plants 2017, 9, 1-18. [CrossRef] [PubMed]

2. Jayanetti, L.; Follet, P. INBAR Technical Report 16: Bamboo in Construction-An Introduction; International Bamboo and Rattan Organization: Beijing, China, 1998.

3. Tahmasebinia, F.; Ma, Y.; Joshua, K.; Sepasgozar, S.M.E.; Yu, Y.; Li, J.; Sepasgozar, S.; Marroquin, F.A. Sustainable architecture creating arches using a bamboo grid shell structure: Numerical analysis and design. Sustainability 2021, 13, 2598. [CrossRef]

4. Shen, L.; Yang, J.; Zhang, R.; Shao, C.; Song, X. The benefits and barriers for promoting bamboo as a green building material in China-An integrative analysis. Sustainability 2019, 11, 2493. [CrossRef]

5. Sungkaew, S.; Teerawattananon, A.; Chindawang, K. Bamboo in Thailand; Center of Excellence for Bamboos, Kasetsart University: Bangkok, Thailand, 2014.

6. International Organization for Standardization. Bamboo-Determination of Physical and Mechanical Properties-Part II: Laboratory Manual; ISO 22157-2; ISO: Geneva, Switzerland, 2004.

7. International Organization for Standardization. Bamboo-Determination of Physical and Mechanical Properties-Part I: Requirement; ISO 22157-1; ISO: Geneva, Switzerland, 2004.

8. Simpson, W.T. Drying and control of moisture content and dimensional changes. In Wood Handbook: Wood as an Engineering Material; Forest Products Laboratory, United States Department of Agriculture: Madison, WI, USA, 1999; pp. 12.1-12.20.

9. Rautkari, L.; Hill, C.A.S.; Curling, S.; Jalaludin, Z.; Ormondroyd, G. What is the role of the accessibility of wood hydroxyl groups in controlling moisture content? J. Mater. Sci. 2013, 48, 6352-6356. [CrossRef]

10. Zhang, Y.; Huang, X.; Yu, Y.; Yu, W. Effects of internal structure and chemical compositions on the hygroscopic property of bamboo fiber reinforced composites. Appl. Surf. Sci. 2019, 492, 936-943. [CrossRef]

11. Kumar, S.; Dobriyal, P.B. Treatability and flow path studies in bamboo. Part 1. Dendrocalamus strictus nees. Wood Fiber Sci. 1992, 24, 113-117.

12. Huang, P.; Chang, W.S.; Ansel, M.P.; John Chew, Y.M.; Shea, A. Density distribution profile for internodes and nodes of Phyllostachys edulis (Moso bamboo) by computer tomography scanning. Constr. Build. Mater. 2015, 93, 197-204. [CrossRef]

13. Huang, X.; Li, F.; De Hoop, C.F.; Jiang, Y.; Xie, J.; Qi, J. Analysis of Bambusa rigida bamboo culms between internodes and nodes: Anatomical characteristics and physical-mechanical properties. For. Prod. J. 2018, 68, 157-162. [CrossRef]

14. Green, D.W.; Winandy, J.E.; Kretschmann, D.E. Mechanical properties of wood. In Wood Handbook: Wood as an Engineering Material; Forest Products Laboratory, United States Department of Agriculture: Madison, WI, USA, 1999; pp. 4.1-4.45.

15. Abd Latif, M.; Liese, W. Culm characteristics of two bamboos in relation to age, height and site. In Bamboo for Sustainable Development, Proceedings of the 5th International Bamboo Congress and 6th International Bamboo Workshop, San José, Costa Rica, 2-6 November 1998; Kumar, A., Ramanuja Rao, I.V., Sastry, C., Eds.; VSP B.V.: Zeist, The Netherlands, 1998; pp. $223-233$.

16. Chaowana, P.; Barbu, M.C.; Frühwald, A. Bamboo-A functionally graded composite material. For. Prod. J. 2015,65, S48-S53.

17. Dixon, P.G.; Ahvenainen, P.; Aijazi, A.N.; Chen, S.H.; Lin, S.; Augusciak, P.K.; Borrega, M.; Svedström, K.; Gibson, L.J. Comparison of the structure and flexural properties of Moso, Guadua and Tre Gai bamboo. Constr Build. Mater. 2015, 90, 11-17. [CrossRef]

18. Akinbade, Y.; Harries, K.A.; Flower, C.V.; Nettleship, I.; Papadopoulos, C.; Platt, S. Through-culm wall mechanical behaviour of bamboo. Constr Build. Mater. 2019, 216, 485-495. [CrossRef]

19. Malanit, P.; Barbu, M.C.; Frühwald, A. Mechanical Properties of Sweet Bamboo Dendrocalamus asper. J. Bamboo Ratt. 2009, 8 , $151-160$.

20. Shao, Z.P.; Zhou, L.; Liu, Y.M.; Wu, Z.M.; Arnaud, C. Differences in structure and strength between internode and node sections of Moso bamboo. J. Trop For. Sci. 2010, 22, 133-138.

21. Oka, G.M.; Triwiyono, A.; Awaludin, A.; Siswosukarto, S. Effects of node, internode and height position on the mechanical properties of Gigantochloa atroviolacea bamboo. Procedia Eng. 2014, 95, 31-37. [CrossRef]

22. Chaowana, P.; Barbu, M.C. Bamboo: Potential material for biocomposites. In Lignocellulosic Fibre and Biomass-Based Composite Materials-Processing, Properties and Application; Jawaid, M., Tahir, P.M., Saba, N., Eds.; Woodhead Publishing: Duxford, UK, 2017; pp. 259-289.

23. Lee, A.W.C.; Bai, X.; Peralta, P.N. Selected physical and mechanical properties of giant timber grown in South Carolina. For. Prod. J. 1994, 44, 40-46.

24. Srivaro, S.; Jakranod, W. Comparison of physical and mechanical properties of Dendrocalamus asper Backer specimens with and without nodes. Eur. J. Wood Wood Prod. 2016, 74, 893-899. [CrossRef]

25. Ikponmwosa, E.; Fapohunda, C.; Kolajo, O.; Eyo, O. Structural behaviour of bamboo-reinforced foamed concrete slab containing polyvinyl wastes (PW) as partial replacement of fine aggregate. J. King Saud Univ. Sci. 2015, 16, 1-8. [CrossRef]

26. Javadian, A.; Wielopolski, M.; Smith, I.F.C.; Hebel, D.E. Bond-behavior study of newly developed bamboo-composite reinforcement in concrete. Constr. Build. Mater. 2016, 122, 110-117. [CrossRef] 